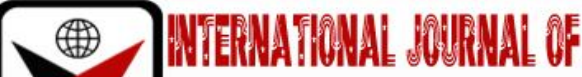

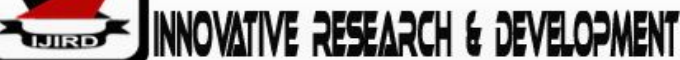

ISSN 2278 - 0211 (Online)

\section{The Effect of Self-Efficacy, Gender, Habits of Mind to Cognitive Learning Outcomes of High School Student on Biology Subject, Indonesia}

\begin{tabular}{|c|}
\hline Dinda Yumarita Sari \\
Faculty, Department of Mathematics and Science, State University of Jakarta, Indonesia \\
Dr. Diana Vivanti Sigit \\
Faculty, Department of Mathematics and Science, State University of Jakarta, Indonesia \\
Dr. Adisyahputra \\
Faculty, Department of Mathematics and Science, State University of Jakarta, Indonesia
\end{tabular}

\begin{abstract}
Self efficacy was defined as someone beliefs to control situation and make some positive results. Self efficacy affected an activity that choosen by an individual as an action to solve problem and have a final result. Males and females had different type of self efficacy. So that could impact to achivement of study. Student that had difficulty of problem solving, could be helped by make a thinking as a habit. Habits of thinking and act that we used to solve problems was known by habits of mind. This study was purposed to find out effect of self efficacy, gender, and habits of mind to Biology subject achivement. The highest mean score in the group of students with high efficacy level, low habits of mind, and women gendered is 91.82. The lowest mean score of the test in the group of students with high efficacy level, low habits of mind, and men gendered is equal to 70.91. Based on the test results on the hypothesis with ANOVA factorial test obtained sig value $0.009 \varangle 0.05$. It could be concluded that there was an interaction among self efficacy, habits of mind, and gender in influencing cognitive learning outcomes.
\end{abstract}

Keywords: Self-efficacy, gender, habits of mind, cognitive learning outcomes

\section{Introduction}

Self-efficacy was one component of social learning theory proposed by Bandura (1977). According to Bandura (in Santrock, 2008), "Self efficacy is the ability of a person to be able to master and produce positive results." Self-efficacy is also the core of an individual in deciding something and finishing a duty in his/ her life (Pajares, 2006).

Self efficacy was an affective factor that related to the assessment of each individual about how well they were doing an action or solving a problem. Self efficacy also determines about how one's beliefs, thoughts, and behaviors which are demonstrated through action and problem solving (Bandura in Ekici et al., 2012). Self efficacy affected an activity that choosen by an individual as an action to solve problem and have a final result. Male self efficacy was different from female, so this gender differences would also have an impact on the performance and learning outcomes of each learner (Schunk, 1984).

Psychologically, gender differences were found in several aspects, including interests, intelligence, talent, motivation, and cognitive learning outcomes. All these aspects could affect how the learning process and learning outcomes were (Purwanto, 2006).

Learners who had difficulty in solving a problem could be helped by getting used to think and act when they were facing the problem. The habit of thinking and acting was better known as habits of mind. Habits of mind was a pattern of intellectual behavior that helped learners produced productive action (Costa and Kalick, 2008). The implementation of habits of mind was expected to help learners became problem solvers and wise decision makers so that would realize the students became intellectual, emotional, and social superior learners. Therefore, habits of mind had an important role in every learning process.

In order to obtain good learning outcomes, learners must have confidence that they were able to do and solve problems in their task properly and correctly. Continuous problems solving could make the learners mindset became familiar and had several alternative ways to solve the problem. So, the learning results obtained would get better. This study was purposed to find out effect of self efficacy, gender, and habits of mind to Biology subject achivement. 


\section{Research Method}

The research method used was ex-post facto. The research setting was in SMA Bina Dharma East Jakarta. The study was conducted in November-December 2017. The target population in this study were all of grade XI MIPA students of SMA Bina Dharma East Jakarta who followed the Biology subject in the academic year of 2016/ 2017. The classes XI MIPA consisted of four classes in this school. Sampling is done by multistage random sampling technique. First, SMA Bina Dharma East Jakarta, as a place of this research was selected by purposive sampling. Secondly, the research class, XI MIPA was chosen by purposive sampling, and finally, sampling 92 of 120 students were choosen by simple random sampling technique. In this research, there were three independent variables, they were self-efficacy (X1), habits of mind (X2), and gender (X2), while the dependent variable was the results of cognitive learning in biology subjects (Y).

This study used self-efficacy instruments and thinking habits instruments. Each instruments consisted of 29 items and 39 items that had been validated. The item was in the form of statement with choices as Strongly Agree, Agree, Disagree and Strongly Disagree. The item reliability was calculated by using Cronbarch Alpha formula. Based on the calculation results, the overall reliability value of self efficacy instruments was 0.7 and the habits of minds instruments was 0.8 which were categorized enough by Arikunto (2010).

Scores of cognitive learning outcomes on Biology subject were obtained from Year End Assesment (YEA). Year End Assessment consisted of 35 multiple choice items with 23 validated items.

\section{Findings and Discussions}

In the self efficacy variables, from 92 students as many as 47 students had high self efficacy with the number of 18 male students and 29 female students. Then, there were 45 students who had low self efficacy which consisted of 28 male students and 17 female students. The mean score of students with high self efficacy group was 81, while the students with low self efficacy group was 80 . Based on the self efficacy data collection by using questionnaires, it was found that male students with high self efficacy were less than female students. However the male students with low self efficacy were more than female students.

In the habits of mind variables, from 92 students as many as 50 students had high thinking habits with the number of 22 male students and 28 female students. Then, there were 42 students who had low habits of mind which consisted of 24 male students and 18 female students. The mean score of students with high habits of mind group was 80, whereas students with low habits of mind group was 81. Based on the habits of mind data collection by using questionnaires, it was found that male students with high habits of mind were less than female students. However the male students with low self efficacy were more than female students.

\begin{tabular}{|c|c|c|c|c|c|c|c|}
\hline \multicolumn{8}{|c|}{ Dependent Variable : Biology Subject Cognitive Learning Results } \\
\hline Self Efficacy & $\begin{array}{l}\text { Habits of } \\
\text { Mind }\end{array}$ & Gender & Mean & $\begin{array}{l}\text { Standard } \\
\text { Deviation }\end{array}$ & $\mathrm{N}$ & Max & Min \\
\hline \multirow[t]{4}{*}{ High } & \multirow[t]{2}{*}{ High } & Male & 82.50 & 8.10 & 10 & 91 & 69 \\
\hline & & Female & 81.62 & 9.36 & 23 & 91 & 62 \\
\hline & \multirow[t]{2}{*}{ Low } & Male & 70.91 & 16.40 & 8 & 91 & 40 \\
\hline & & Female & 91.82 & 4.87 & 7 & 97 & 85 \\
\hline \multirow[t]{4}{*}{ Low } & \multirow[t]{2}{*}{ High } & Male & 80.01 & 16.64 & 13 & 91 & 31 \\
\hline & & Female & 84.55 & 12.97 & 6 & 97 & 65 \\
\hline & \multirow[t]{2}{*}{ Low } & Male & 78.22 & 7.08 & 17 & 86 & 63 \\
\hline & & Female & 78.87 & 6.21 & 12 & 91 & 69 \\
\hline
\end{tabular}

Table 1: The Mean Score of Biology Subject Cognitive Learning Results in Each Research Group

Based on the year end assessment for biology subjects, the highest score was 97 and the lowest score was 31 with an overall mean score of 80.62. From the Table 1 above, it could be seen that the highest mean score was in the group of students with high self efficacy, low habits of mind, and female gendered which was 91.82. The lowest mean score value was in the group of students with high self efficacy, low habits of mind, and male gendered which was equal to 70.91. 


\begin{tabular}{|c|c|c|c|c|c|}
\hline \multicolumn{7}{|c|}{ Tests of Between-Subjects Effects } \\
\hline Dependent Variable:HBB & & & & \\
\hline Source & $\begin{array}{c}\text { Type III Sum } \\
\text { of Squares }\end{array}$ & $\mathrm{df}$ & Mean Square & $\mathrm{F}$ & Sig. \\
\hline $\begin{array}{c}\text { Corrected } \\
\text { Model }\end{array}$ & $1920.749 \mathrm{a}$ & 7 & 274.393 & 2.424 & .026 \\
\hline Intercept & 515043.837 & 1 & 515043.837 & $4.550 \mathrm{E} 3$ & .000 \\
\hline $\mathrm{SE}$ & 33.810 & 1 & 33.810 & .299 & .586 \\
\hline $\mathrm{KB}$ & 486.852 & 1 & 486.852 & 4.301 & .036 \\
\hline $\mathrm{G}$ & 785.161 & 1 & 785.161 & 6.936 & .010 \\
\hline $\mathrm{SE}{ }^{*} \mathrm{~KB}$ & 42.495 & 1 & 42.495 & .375 & .542 \\
\hline $\mathrm{SE} * \mathrm{G}$ & 275.671 & 1 & 275.671 & 2.435 & .122 \\
\hline $\mathrm{KB} * \mathrm{G}$ & 461.609 & 1 & 461.609 & 4.078 & .045 \\
\hline $\mathrm{SE}^{*} \mathrm{~KB} * \mathrm{G}$ & 805.015 & 1 & 805.015 & 7.112 & .009 \\
\hline Error & 9508.414 & 84 & 113.195 & & \\
\hline Total & 609707.000 & 92 & & & \\
\hline Corrected Total & 11429.163 & 91 & & & \\
\hline
\end{tabular}

Table 2: Hypothesis Test of Biology Subject Learning Results

Data with Factorial ANOVA Test

a. R Squared =, 168 (Adjusted R Squared $=, 099$ )

Based on the hypothesis test result obtained, it indicated that self efficacy did not affect the results of Biology subject learning. The result of this study was different with the previous research which stated that self efficacy significantly affected academic ability (Shkullaku, 2013). When a student believed that he or she could complete a job, so that that student would do his work seuriously and was expected to get good results.

Self efficacy could specifically predict the outcome or goal to be achieved. But it could not determine the results achieved (Yi Jiang et al., 2013). Bandura (1994) mentioned that the effect of self efficacy on a person's cognitive process varied greatly. This cognitive process included the goals achieved, steps taken in achieving the goals, and preparing the alternative steps to achieve the goals. Improper steps taken would affect the results achieved. So, it did not always got the satisfactory results. The influence of the environment, such as friends' differences of opinion could decrease students' self efficacy. This might affect the steps the students took in completing the task so that the results achieved were not satisfactory.

Gender affected cognitive learning outcomes. It was similar to previous research which also mentioned that gender affected cognitive learning outcomes (Tenaw, 2013). This study said that female students tended to have higher cognitive learning outcomes than male students.

Most of the material in the biology subjects were analysis and recitation. One of the teacher methods in delivering the material was lecture method. Female students had more detail memory and had the ability to hear and differentiate better, so they could be more skilled in doing the task (Muhammad, 2011).

Habits of mind gave the influence to cognitive learning outcomes. The role of teachers in applying the habits of mind in the classroom environment was very important. Teacher could explore, teach, and observe students' thinking skills. Once students' thinking skills are established, they already had a habit of behaving intellectually (Johnson et al., 2005).

Based on the result of the hypothesis test, it was obtained that there was no interaction between self efficacy and gender in affecting cognitive learning outcomes. Tenaw (2013) stated that gender did not affect the self efficacy of a person.

Self efficacy in everyone would affect a person's cognitive process and that process varied. This efficacy arised from within a person without being influenced whether he was male or female. So, it could be said that there was no interaction occured in this study. This could be caused by several factors such as the class condition was less conducive at the time of questionnaire filling which resulted in the students' answer were not in accordance with their situation.

Self efficacy variables and habits of mind variables did not show any interaction in influencing cognitive learning outcomes. The absence of interaction between self efficacy and habits of mind in influencing cognitive learning outcomes was thought due to self efficacy and habits of mind were two different things. Self efficacy could be affected by pressure, drive, and mood in shaping a belief to do something. If a student was in a bad mood and quite heavy pressure in carrying out a task, then the result achieved was not maximal.

Habits of mind and gender had interactions in influencing cognitive learning outcomes. In the habits of mind data table, there were amount differences of female and male students. Female students who had high habits of mind were more than male students. This result was in line with previous research that stated gender reinforced one's habits of mind (Al-Assaf, 2017).

According to Kail (2005), "Girls are more resistant to face environmental pressure." So, even in a less comfortable situation, female student could finish the job well. Boys more often broke school rules (Diaz, 2006). Thus, the male student did not finish the job well or not done at all. 
Based on the test results on the hypothesis with ANOVA factorial test obtained sig. value $0.009 \varangle 0.05$. It could be said that there was an interaction among self efficacy, habits of mind, and gender in influencing cognitive learning outcomes.

Tenaw (2013) in the previous study found that there was no influence between self efficacy and gender, there was influence between gender and learning outcomes, and there was influence of self efficacy toward learning outcomes. The fact was that both female students and male students were equally good at solving problems in the classroom. However, male students tended to be more active in the classroom.

In contrast to Tenaw, Shkullaku (2013) found that there was a gender effect on self efficacy but there was no gender effect on learning outcomes in his research. The environment stereotype that still thought that the man is the strongest affected one's self efficacy. Thus, the man will believe that he is the strongest and will solve the problem well. While woman would believe that she is much weaker than man, so she can not solve a problem. However, one's self efficacy could change.

Siahi and Maiyo (2015), in his research, stated that habits of mind affected learning outcomes. The level of student understanding depended on the amount of time they spent in studying. The time used by a student to study could help him/ her master a learning material, so when it came to a test or task, they could finish it well and quickly. Then self efficacy, habits of mind, and gender had an interaction in influencing Biology subject cognitive learning outcomes.

\section{Conclusions}

Based the research results, it could be concluded that there was no effect of self efficacy on cognitive learning outcomes in Biology subject. However, there was an effect of gender and habits of mind on cognitive learning outcomes in Biology subject. The enhancement of Biology subject cognitive learning outcomes could be helped by enhancing self efficacy and instilling habits of mind to students, both male and female.

To Biology subject teachers, it was advised to improve students' self efficacy by motivating students to always believe that they were capable in accomplishing tasks well and to train students in analyzing and observing a problem better in order to sharpen their thinking skills.

\section{References}

i. Al-Assaf, J. A. A. 2017. The Teaching Habits of Mind, Their Relationship To Positive Behavior of Social Studies Teachers in Lower Basic Stage In University District - The Capital (Amman). Journal of Curriculum and Teaching, Vol.6, No. 2

ii. Arikunto, S. 2010. Dasar - Dasar Evaluasi Pendidikan. Jakarta: Bumi Aksara.

iii. Bandura, A. 1994. Self Efficacy: Toward Unifying Theory. Psychological Review 1977, vol.

iv. 84. Number 2.195.

v. Britner, S.L., dan Pajares, F. 2006. Sources of Science Self-Efficacy Beliefs of Middle School Students. Journal of Research in Science Teaching, 43(5), 485.

vi. Costa, A.L. dan Kallick, B. 2008. Describing 16 Habits of Mind, Habits of Mind: A Developmental Series. Alexandria, VA: Assosciation for Supervision and Curriculum Development.

vii. Diaz, C. F. 2006. Touch The Future Teach. USA: Pearson Education, 248.

viii. Ekici, G., Fettahlioglu, P., dan Cibik, A.S. 2012. Biology Self Efficacy Beliefs of The Students Studying in the Department of Biology and Department of Biology Teaching. International Online Journal of Educational Sciences. $4,(1), 48-68$.

ix. Johnson, B., Ritledge, M., dan Poppe, M. 2005. Habits of Mind: A Curiculum for Community High School of Vermont Student. Vermont: Vermont Consultant for Lamguage and Learning.

x. Kail, R. V. 2005. Human Development. USA: University of West Florida, 203.

xi. Muhammad, A. 2011. Rahasia Perbedaan Otak Pria dan Wanita. Jakarta: Flashbooks, 110.

xii. Pajares, F. 2006. Self Efficacy Adolescent. USA: IAP, 339.

xiii. Purwanto, N. 2006. Psikologi Pendidikan. Bandung: PT. Remaja Rosdakarya.

xiv. Santrock, J. W. 2008. Educational Psychology, terjemahan Tri Wibowo B.S., Jakarta: Kencana, 194.

xv. Schunk, D. H. 1984. The self-efficacy perspective on achievement behavior. Educational Psychologist, 19, 199-218.

xvi. Shkullaku, R. 2013. The Relationship between Self - efficacy and Academic Performance in the Context of Gender among Albanian Students. European Academic Research, Vol. I, Issue 4

xvii. Siahi, E. A. \& Maiyo, J. K. 2015. Study of the relationship between study habits and academic achievement of students: A case of Spicer Higher Secondary School, India. International Journal of Educational Administration and Policy Studies. Vol. 7(7), pp. 134-141

xviii. Tenaw, Y. A. 2013. Relationship Between Self-Efficacy, Academic Achievement And Gender In Analytical Chemistry At Debre Markos College Of Teacher Education. AJCE, 3(1).

xix. Yi Jiang, Juyeon Song, Minhye Lee \& Mimi Bong, 2013. Self-efficacy and achievement goals as motivational links between perceived contexts and achievement. An International Journal of Experimental Educational Psychology. Vol. 34, Issue 1. 